Article

\title{
Green Synthesis of Silver Nanoparticles with Culture Supernatant of a Bacterium Pseudomonas rhodesiae and Their Antibacterial Activity against Soft Rot Pathogen Dickeya dadantii
}

\author{
Afsana Hossain $1,2,+$, Xianxian Hong ${ }^{1,+}{ }^{+}$, Ezzeldin Ibrahim ${ }^{1}$, Bin Li ${ }^{1}$, Guochang Sun ${ }^{3}$, \\ Youqing Meng ${ }^{4}$, Yanli Wang ${ }^{3, *}$ and Qianli An ${ }^{1, *(1)}$ \\ 1 State Key Laboratory of Rice Biology and Ministry of Agriculture Key Lab of Molecular Biology of Crop \\ Pathogens and Insects, Institute of Biotechnology, Zhejiang University, Hangzhou 310058, China; \\ afsana_07@yahoo.com (A.H.); 21816076@zju.edu.cn (X.H.); ezzelbehery8818@yahoo.com (E.I.); \\ libin0571@zju.edu.cn (B.L.) \\ 2 Department of Plant Pathology and Seed Science, Sylhet Agricultural University, Sylhet 3100, Bangladesh \\ 3 State Key Laboratory for Quality and Safety of Agro-products (in prepared), Institute of Plant Protection and \\ Microbiology, Zhejiang Academy of Agricultural Sciences, Hangzhou 310021, China; sungc01@sina.com \\ 4 General Station of Plant Protection and Quarantine of Zhejiang Province, Hangzhou 310020, China; \\ yqmeng_77@163.com \\ * $\quad$ Correspondence: ylwang88@aliyun.com (Y.W.); an@zju.edu.cn (Q.A.); Tel.: +86-571-8604-9815 (Y.W.); \\ +86-571-8898-2255 (Q.A.) \\ + A.H. and X.H contributed equally to this work.
}

Received: 29 May 2019; Accepted: 19 June 2019; Published: 21 June 2019

\begin{abstract}
Bacterial stem and root rot disease of sweet potato caused by Dickeya dadantii recently broke out in major sweet potato planting areas in China and calls for effective approaches to control the pathogen and disease. Here, we developed a simple method for green synthesis of silver nanoparticles (AgNPs) using bacterial culture supernatants. AgNPs synthesized with the cell-free culture supernatant of a bacterium Pseudomonas rhodesiae displayed the characteristic surface plasmon resonance peak at $420-430 \mathrm{~nm}$ and as nanocrystallites in diameters of 20-100 nm determined by transmission electron microscopy, scanning electron microscopy, and X-ray diffraction spectroscopy. Functional groups associated with proteins in the culture supernatant may reduce silver ions and stabilize AgNPs. The AgNPs showed antibacterial activities against $D$. dadantii growth, swimming motility, biofilm formation, and maceration of sweet potato tubers whereas the culture supernatant of P. rhodesiae did not. AgNPs $\left(12 \mu \mathrm{g} \cdot \mathrm{ml}^{-1}\right)$ and $\mathrm{AgNO}_{3}\left(50 \mu \mathrm{g} \cdot \mathrm{ml}^{-1}\right)$ showed close antibacterial activities. The antibacterial activities increased with the increase of AgNP concentrations. The green-synthesized AgNPs can be used to control the soft rot disease by control of pathogen contamination of sweet potato seed tubers.
\end{abstract}

Keywords: green synthesis; silver nanoparticles; Pseudomonas rhodesiae; soft rot; sweet potato

\section{Introduction}

Gram-negative bacteria belonging to the genera Pectobacterium and Dickeya are broad-host-range pathogens causing devastating soft rot diseases of ornamental and crop plants [1,2]. Some Dickeya species cause foot rot of rice [3,4], stalk rot of maize [5], blackleg and soft rot of potato [6-8], and stem and root rot of sweet potato $[9,10]$, threatening staple food security.

Outbreaks of soft rot diseases of staple food crops in the last two decades worldwide indicate the failure in management of soft rot Pectobacterium and Dickeya. Crop varieties resistant to soft rot 
Pectobacterium and Dickeya are lacking while large-scale use of effective antibiotics is no longer allowed in fields due to the risks of introducing resistance to bacterial pathogens of humans or animals [2]. It is imperative to integrate conventional and innovative methods to effectively control the soft rot bacteria.

Nanoparticles with a size range of 1-100 nm display unique properties of nanomaterials with a wide range of applications. Using nanoparticles as novel antimicrobial agents against broad-spectrum microbes including Gram-positive and Gram-negative multidrug-resistant bacteria, fungi, protozoa, and viruses has brought revolutions in the field of health, food, and agriculture technology. Physical, chemical, and biological methods have been developed to synthesize nanoparticles [11-13]. Nanoparticles produced by various methods have been recently tested against soft rot bacteria in vitro [14-18].

Green synthesis of nanoparticles, which uses eco-friendly and cost-effective reducing and stabilizing agents from plants, microbes, and other natural resources to produce nanoparticles without the use of toxic chemicals or stringent conditions, promotes the sustainable use of nanoparticles [12,13]. Green synthesis of nanoparticles with bacteria and cell-free extracts has shown advantages of easy handling, easy downstream processing, rapid scale-up processing, and easy genetic modification [19]. Extracellular polymeric substances produced by bacteria consist of polysaccharides, proteins, nucleic acids, uronic acids, and lipids. They contain functional groups, such as carboxyl, phosphoric, amine, and hydroxyl groups, which have adsorptive and adhesive properties and can serve as ligands and binding sites of metals [20,21]. Cell-free supernatants of bacterial cultures containing extracellular polymeric substances have been demonstrated to be effective for rapid, inexpensive, and safe syntheses of nanoparticles [22-26].

Outbreaks of bacterial stem and root rot disease of sweet potato caused by D. dadantii (former Erwinia chrysanthemi) [27] recently occurred in major sweet potato planting areas in China $[9,10,28]$ and call for effective approaches to control the pathogen and disease. The aim of this study was to synthesize silver nanoparticles (AgNPs) using cell-free culture supernatants (CFCS) of plant growth-promoting bacteria (Bacillus amyloliquefaciens strain A3, Paenibacillus polymyxa strain ShX304, and Pseudomonas rhodesiae strain G1) and determine their antibacterial activities against the pathogen $D$. dadantii.

\section{Results and Discussion}

AgNPs were synthesized by incubation of $\mathrm{AgNO}_{3}$ with CFCS of P. rhodesiae G1 and B. amyloliquefaciens A3 but not Paenibacillus polymyxa ShX304, indicated by the color change of the mixture from light yellow to dark brown (Figure 1a), as previous studies have shown [22-24,29]. The success and failure of production of AgNPs by incubation of $\mathrm{AgNO}_{3}$ with $\mathrm{CFCS}$ of different strains suggest that the components of CFCS determine the green synthesis of AgNPs.

CFCS $[50 \%(v / v)]$ of B. amyloliquefaciens and Paenibacillus polymyxa generated clearing zones against D. dadantii in nutrient agar with diameters of $14.5 \pm 0.3 \mathrm{~mm}$ and $12.0 \pm 0.4 \mathrm{~mm}$, respectively, including the diameter $(7 \mathrm{~mm})$ of the holes, whereas CFCS of $P$. rhodesiae did not. $\mathrm{AgNO}_{3}\left(50 \mu \mathrm{g} \cdot \mathrm{mL}^{-1}\right), \mathrm{AgNPs}$ $\left(50 \mu \mathrm{g} \cdot \mathrm{mL}^{-1}\right)$ synthesized with CFCS of B. amyloliquefaciens, and AgNPs $\left(50 \mu \mathrm{g} \cdot \mathrm{mL}^{-1}\right)$ synthesized with CFCS of $P$. rhodesiae generated clearing zones with diameters of $13.5 \pm 0.4 \mathrm{~mm}, 17.0 \pm 0.4 \mathrm{~mm}$, and $22.0 \pm 0.3 \mathrm{~mm}$, respectively, including the diameter $(7 \mathrm{~mm})$ of the holes. AgNPs produced by incubation of CFCS of Bacillus bacteria including B. amyloliquefaciens [26,29] and their antibacterial activities have been demonstrated by previous studies [22,23,26,29-31]. Here, we showed that both CFCS of B. amyloliquefaciens and AgNPs synthesized with CFCS of B. amyloliquefaciens had antibacterial activities. On the other hand, CFCS of $P$. rhodesiae did not inhibit $D$. dadantii growth whereas AgNPs synthesized with CFCS of $P$. rhodesiae showed the strongest inhibition activity, suggesting that the antibacterial activity of AgNPs synthesized with CFCS of $P$. rhodesiae is independent of the components in CFCS binding to AgNPs. Therefore, to avoid interference with antibacterial activities by components of CFCS, we chose AgNPs synthesized with the CFCS of P. rhodesiae to characterize the green-synthesized AgNPs and determine their antibacterial activities against D. dadantii. 


\subsection{Characterization of AgNPs Synthesized with CFCS of P. Rhodesiae}

AgNPs synthesized with CFCS of $P$. rhodesiae displayed a clear surface plasmon resonance peak at $420-430 \mathrm{~nm}$ (Figure 1a) in the range of 350-450 $\mathrm{nm}$ for characteristic absorption peak of AgNPs by UV-Visible spectroscopy [32], as previous studies have shown [22-24,29].

The presence of functional groups in CFCS of $P$. rhodesiae responsible for the reduction of $\mathrm{Ag}^{+}$and stabilization of the AgNPs was identified by FTIR spectroscopy. The FTIR spectrum shows absorption bands at wave numbers 3416, 2920, 1641, 1530, 1394, 1265, and $523 \mathrm{~cm}^{-1}$ (Figure 1b). The major band at $3416 \mathrm{~cm}^{-1}$ is attributed to $\mathrm{N}-\mathrm{H}$ stretching vibrations; the distinctive peak at $1641 \mathrm{~cm}^{-1}$ is attributed to $-C=O$ carbonyl group and $-C=C$ stretching vibrations; the bands at 2920, 1530, 1394, and $1265 \mathrm{~cm}^{-1}$ are attributed to $\mathrm{C}-\mathrm{H}$ stretching vibrations, $\mathrm{C}=\mathrm{N}$ bond of Amide II, $\mathrm{O}-\mathrm{H}$ deformation vibrations, and $\mathrm{C}-\mathrm{N}$ stretching amine vibrations, respectively; the band at $523 \mathrm{~cm}^{-1}$ is attributed to $\mathrm{C}-\mathrm{Br}$ stretching, which is characteristic of alkyl halides. The presence of these groups confirms the presence of proteins in CFCS of $P$. rhodesiae and suggests that these functional groups reduce $\mathrm{Ag}^{+}$for the synthesis of AgNPs and bind to AgNPs for the stabilization of the nanoparticles [30,33-35].

The nanoscale size of the AgNPs synthesized with CFCS of P. rhodesiae was confirmed by transmission electron microscopy and scanning electron microscopy. The AgNPs were generally uniform and spherical about 20-100 $\mathrm{nm}$ in diameter (Figure 1c,d).

The nanoscale size and crystalline nature of the AgNPs were confirmed by X-ray diffraction analysis. The X-ray diffraction spectrum of the product showed the characteristic Bragg reflection peaks of the Ag nanocrystallites at $2 \theta$ values of $32.23^{\circ}, 46.19^{\circ}, 54.78^{\circ}$, and $76.70^{\circ}$. The four peaks correspond to (1 11 1), (2 00$),(220)$, and (3 11 1) (Figure 1e) crystalline planes of the face-centered cubic silver, which were identified by comparing with the standard powder diffraction card of $\mathrm{Ag}^{0}$ (JCPDS Card no. 04-0783) in the Joint Committee on Powder Diffraction Standards library [31,35]. The average particle size of the AgNPs $(49.5 \mathrm{~nm})$ can be calculated using Debye-Scherrer formula: $D=K \lambda /(\beta \operatorname{Cos} \theta)$, where $D$ is the average crystalline size of the nanoparticles, $K$ is the Scherrer constant $(0.94), \lambda$ is the $\mathrm{X}$-ray wavelength $(0.1546 \mathrm{~nm}), \beta$ is the full width at half maximum of the $\mathrm{X}$-ray diffraction peak, and $\theta$ is the Bragg angle [33].

The predominance of Ag element in the AgNPs product was identified by energy dispersive spectroscopy. The AgNPs display typical optical absorption peak of Ag element at about $3 \mathrm{KeV}$ (Figure 1f), as previous studies have shown $[14,15,23,29,31,36]$. The wt $\%$ of $\mathrm{Ag}$, chlorine $(\mathrm{Cl})$, and aluminium (Al) elements were about $83.1 \%, 16.1 \%$, and $0.8 \%$, respectively. 

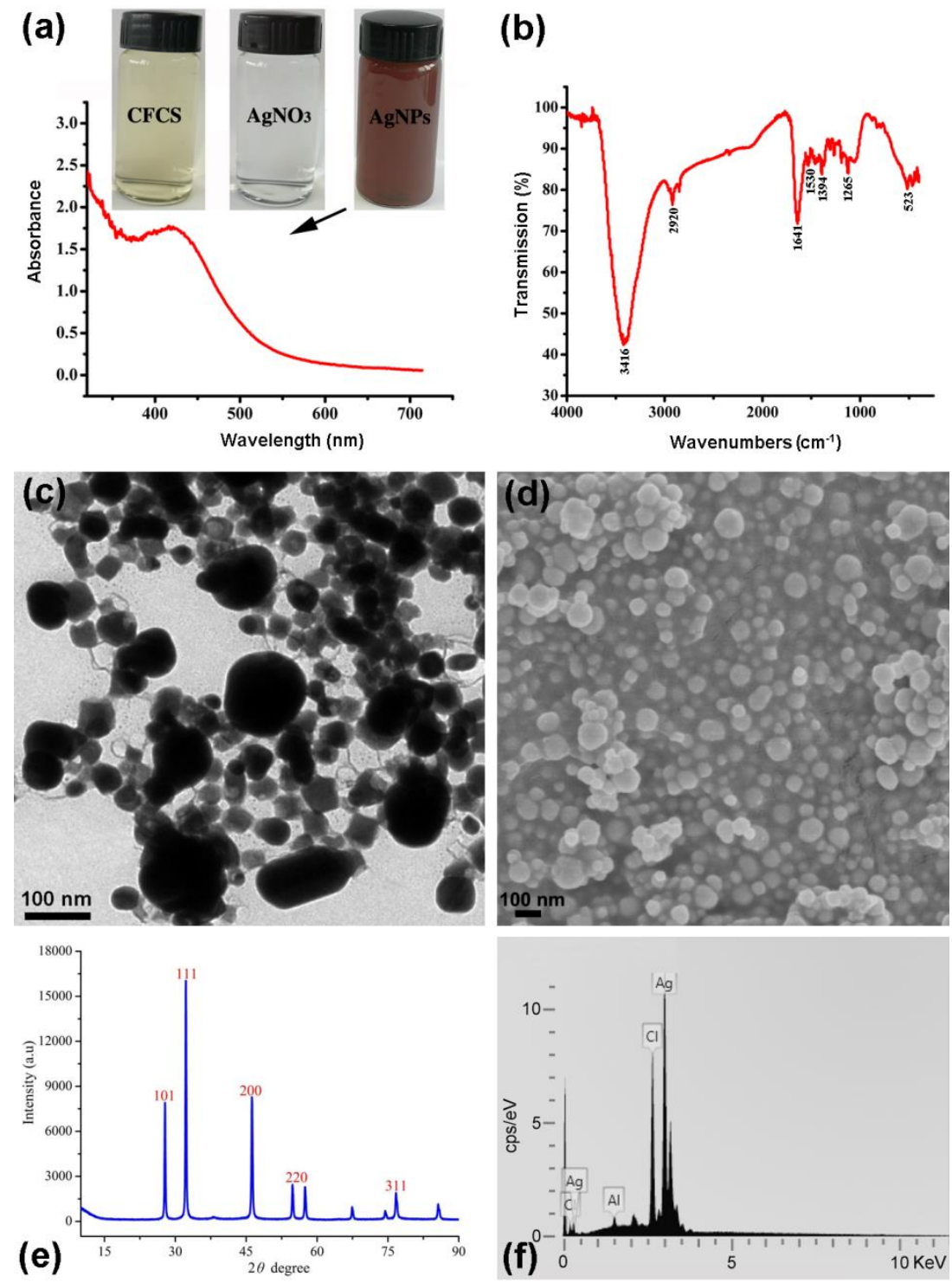

Figure 1. Characterization of silver nanoparticles (AgNPs) synthesized with cell-free culture filtrate (CFCS) of Pseudomonas rhodesiae. (a) UV-Visible absorption spectrum of the dark brown AgNP solution, which was formed by mixture of light yellow CFCS and colorless $\mathrm{AgNO}_{3}$ solution. AgNPs display a clear surface plasmon resonance peak at 420-430 nm. (b) Fourier transform infrared spectrum showing functional groups responsible for the synthesis and stabilization of AgNPs. (c) Transmission electron micrograph showing AgNPs in spherical forms about 20-100 nm in diameter. (d) Scanning electron micrograph showing AgNPs in spherical forms about 20-100 nm in diameter. (e) X-ray diffraction spectrum showing the nanoscale size and crystalline nature of the AgNPs. (f) Energy dispersive spectrum showing the predominance of Ag element in the AgNP product.

\subsection{Antibacterial Activity of AgNPs against D. Dadantii}

CFCS of $P$. rhodesiae did not inhibit $D$. dadantii growth whereas $\mathrm{AgNO}_{3}$ and $\mathrm{AgNPs}$ significantly inhibited $D$. dadantii growth in the $24 \mathrm{~h}$ liquid culture (Figure 2a). Transmission electron microscopy revealed that after treatment with AgNPs $\left(50 \mu \mathrm{g} \cdot \mathrm{mL}^{-1}\right)$ for $2 \mathrm{~h}$, most $D$. dadantii cells underwent cell death, indicated by coagulation and collapse of cytoplasm and disintegration of cell envelopes (Figure 3a). After treatment with AgNPs for $6 \mathrm{~h}$, most $D$. dadantii cells were dead, indicated by disintegration and clearing of cytoplasm (Figure $3 b$ ). In contrast, most control cells had intact cell envelopes and cytoplasm filled in the cells (Figure 3c). Although most AgNPs were washed away with 
water and ethanol during preparation of bacterial cells for electron microscopy, a small number of AgNPs adhering to some bacterial cells were observed (Figure 3b).
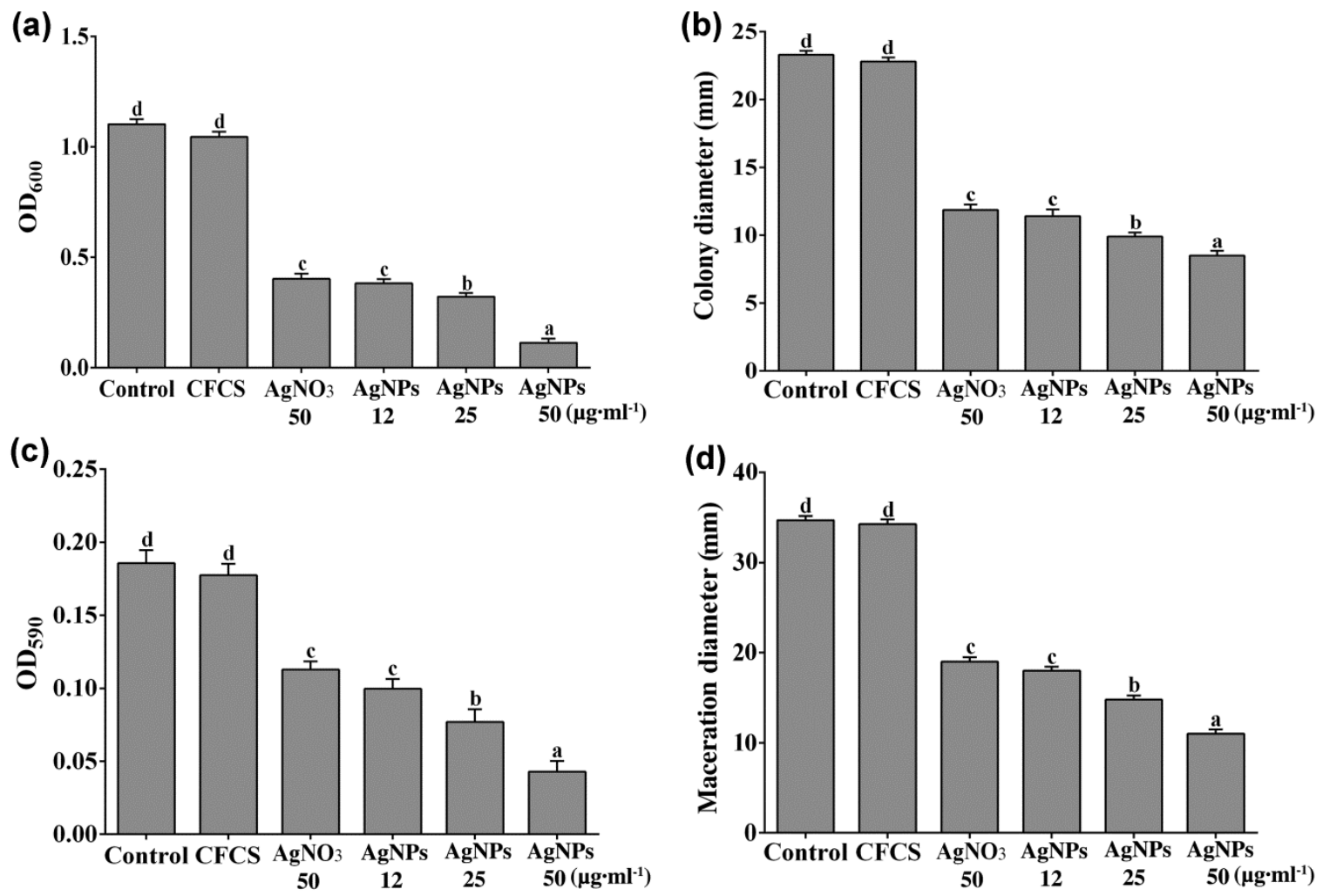

Figure 2. Antibacterial activity against Dickeya dadantii by silver nanoparticles (AgNPs) synthesized with cell-free culture filtrate (CFCS) of Pseudomonas rhodesiae. (a) D. dadantii growth in liquid nutrient broth containing CFCS $(50 \%), \mathrm{AgNO}_{3}\left(50 \mu \mathrm{g} \cdot \mathrm{mL}^{-1}\right)$, or $\operatorname{AgNPs}\left(12,25\right.$, or $\left.50 \mu \mathrm{g} \cdot \mathrm{mL}^{-1}\right)$ indicated by optical density at $600 \mathrm{~nm}\left(\mathrm{OD}_{600}\right)$. (b) Diameters of $D$. dadantii colonies formed on semisolid nutrient agar indicate $D$. dadantii swimming motility with CFCS, $\mathrm{AgNO}_{3}$, or $\mathrm{AgNPs}$. (c) Crystal violet absorbance at $590 \mathrm{~nm}\left(\mathrm{OD}_{590}\right)$ indicates biofilms formed by D. dadantii with CFCS, AgNO3, or AgNPs. (d) Diameters of maceration tissues generated by D. dadantii in sweet potato tuber slices after immersing in $\mathrm{CFCS}, \mathrm{AgNO}_{3}$, or AgNPs. Data are presented as mean values with standard errors (vertical bars); the different letters on the vertical bars indicate significant difference between treatments according to LSD test $(P<0.05)$.
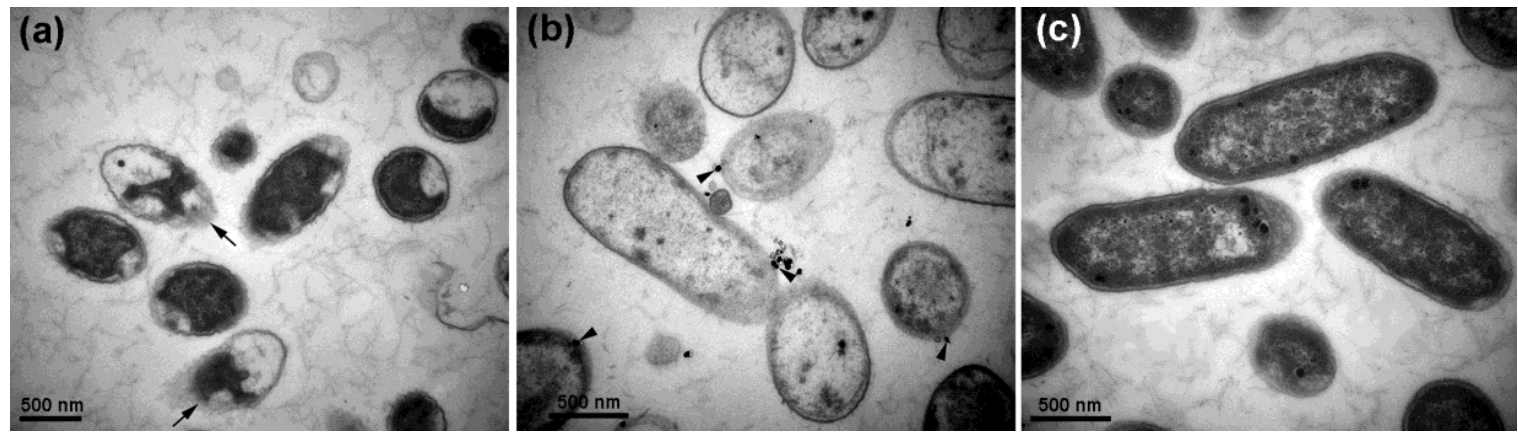

Figure 3. Transmission electron micrographs showing Dickeya dadantii cells treated by silver nanoparticles $\left(50 \mu \mathrm{g} \cdot \mathrm{mL}^{-1}\right)(\mathbf{a}, \mathbf{b})$ and without treatment (c). (a) Coagulation and collapse of cytoplasm after treatment for $2 \mathrm{~h}$. Arrows point to disintegration of cell envelopes. (b) Disintegration and clearing of cytoplasm after treatment for $6 \mathrm{~h}$. Arrowheads point to silver nanoparticles adhering to cell surface. (c) Intact cell envelopes and cytoplasm filled in control cells without treatment. 
D. dadantii grew and swam in the semisolid nutrient medium containing $0.3 \%$ agar and formed a halo about $23 \mathrm{~mm}$ in diameter after $48 \mathrm{~h}$. CFCS of $P$. rhodesiae did not inhibit $D$. dadantii growth and swimming whereas $\mathrm{AgNO}_{3}\left(50 \mu \mathrm{g} \cdot \mathrm{mL}^{-1}\right)$ and $\mathrm{AgNPs}$ significantly inhibited $D$. dadantii growth and swimming in the semisolid medium (Figure 2b).

D. dadantii cells formed biofilms on the surface of the polystyrene microplate wells during the $24 \mathrm{~h}$ incubation. CFCS of $P$. rhodesiae did not inhibit $D$. dadantii biofilm formation whereas $\mathrm{AgNO}_{3}$ and AgNPs significantly inhibited biofilm formation (Figure 2c).

D. dadantii degraded plant cell walls of the sweet potato tuber cells and generated maceration zones about $35 \mathrm{~mm}$ in diameter at $24 \mathrm{~h}$ after inoculation in the sweet potato slices. CFCS of $P$. rhodesiae did not inhibit tissue maceration by $\mathrm{D}$. dadantii (Figure 2d) whereas $\mathrm{AgNO}_{3}$ and $\mathrm{AgNPs}$ significantly inhibited tissue maceration.

$\mathrm{AgNO}_{3}\left(50 \mu \mathrm{g} \cdot \mathrm{mL}^{-1}\right)$ and AgNPs $\left(12 \mu \mathrm{g} \cdot \mathrm{mL}^{-1}\right)$ showed similar extents of inhibitions on $D$. dadantii growth, swimming motility, biofilm formation, and maceration of sweet potato tuber slices. The extents of inhibitions by AgNPs increased with the increase of AgNP concentrations (Figure 2). The in vivo inhibition of tissue maceration was consistent with the in vitro inhibition of bacterial growth, swimming motility, and biofilm formation.

AgNPs may serve as carriers to deliver $\mathrm{Ag}^{+}$more effectively to bacteria membrane and cytoplasm [37]. The antibacterial activity of 20-80 nm AgNPs was primarily assigned to the penetration of bacterial cell envelopes by $\mathrm{Ag}^{+}$released from AgNPs [37-40]. The AgNPs synthesized with CFCS of P. rhodesiae are about 20-100 $\mathrm{nm}$ in diameter and likely inhibit $D$. dadantii growth, swimming motility, and biofilm formation via adhering to bacterial cell surface, releasing toxic $\mathrm{Ag}^{+}$, and damaging cell membranes [41]. $\mathrm{Ag}^{+}$penetrating into the $D$. dadantii cells may generate oxidative stress and bind to proteins and DNA to disturb respiration and DNA replication, leading to cell death [41,42].

D. dadantii movement and attachment to plant surfaces and formation of aggregates or biofilms on plant surfaces, in intercellular spaces, and in xylem vessels are important for survival and completing disease cycles $[43,44]$. AgNPs adhering to bacterial cell surfaces may inhibit $D$. dadantii movement and adhesion to plant surfaces; the following release of $\mathrm{Ag}^{+}$may kill $D$. dadantii cells and remove biofilms.

Soft rot Pectobacterium and Dickeya bacteria are susceptible to AgNPs synthesized by different ways [14-16]. The latently infected seed tuber is one of the major sources of soft rot disease of sweet potato. Physical, chemical, and biological methods are explored to control the disease by avoiding and reducing tuber contamination to produce healthy crops. Here we show that AgNPs effectively inhibit $D$. dadantii growth and maceration of sweet potato tubers. Therefore, using AgNPs is a promising alternative for treatment of seed tubers to avoid and reduce tuber contamination.

In conclusion, we developed a simple method for green synthesis of AgNPs using bacterial culture supernatants. AgNPs synthesized with CFCS of $P$. rhodesiae show potent antibacterial activity against the pathogen $D$. dadantii and can be used to control $D$. dadantii contamination of seed tubers and produce healthy sweet potato crops.

\section{Materials and Methods}

\subsection{Bacteria}

D. dadantii strain CZ1501, which causes bacterial stem and rot disease of sweet potato, was isolated from a stem of a sweet potato plant grown in Hangzhou, Zhejiang Province, China. B. amyloliquefaciens strain A3 isolated from rice seeds [45], Paenibacillus polymyxa strain ShX304 isolated from rhizosphere soils of cotton plants [46], and P. rhodesiae strain G1 isolated from garlic plants were cultured for green synthesis of AgNPs.

\subsection{Synthesis of $A g N P s$}

Strains A3, Sx3, or G1 were cultured in nutrient broth (10 $\mathrm{g}$ tryptone, $3 \mathrm{~g}$ beef extract, $2.5 \mathrm{~g}$ glucose, and $5 \mathrm{~g} \mathrm{NaCl}$ per liter; $\mathrm{pH} \mathrm{7.0)}$ at $30^{\circ} \mathrm{C}$ and $200 \mathrm{rpm}$ for $24 \mathrm{~h}$. CFCS was obtained by centrifugation and 
confirmed by no bacterial growth after incubating $100 \mu \mathrm{L}$ of supernatants on nutrient agar (15 g agar per liter) at $30{ }^{\circ} \mathrm{C}$ for $24 \mathrm{~h}$. CFCS (35 mL) and freshly prepared aqueous $\mathrm{AgNO}_{3}$ (Cat. no. 10018461; Sinopharm, Shanghai, China) solution $(1.0 \mathrm{mM})(115 \mathrm{~mL})$ were mixed in a $250 \mathrm{~mL}$ Erlenmeyer flask, kept in the dark, and shaken at $200 \mathrm{rpm}$ and $30{ }^{\circ} \mathrm{C}$ for $48 \mathrm{~h}$. Nutrient broth $(35 \mathrm{~mL})$ and $\mathrm{AgNO}_{3}$ solution $(1.0 \mathrm{mM})(115 \mathrm{~mL})$ were mixed and used as control. Synthesis of AgNPs was monitored by color change from light yellow to dark brown. The dark brown solution $(2 \mathrm{~mL})$ was mixed with Milli-Q water (2 mL) and analyzed by UV-Visible spectrometry from 200 to $800 \mathrm{~nm}$ at $1 \mathrm{~nm}$ resolution using a Shimadzu UV-2550 spectrometer (Shimadzu, Kyoto, Japan) [24,29]. The dark brown solution containing AgNPs was centrifuged at 27,200× $g$ for $10 \mathrm{~min}$ and the pellet was washed twice with Milli-Q water and freeze-dried. Freeze-dried AgNPs were weighed and a $50 \mathrm{mg} \cdot \mathrm{mL}^{-1}$ stock solution dissolved in Milli-Q water was prepared.

\subsection{Characterization of AgNPs Synthesized with CFCS of P. Rhodesiae}

Functional groups responsible for the synthesis and stabilization of AgNPs were detected by Fourier transform infrared (FTIR) spectroscopy. Freeze-dried AgNP powders (1 mg) were mixed with $\mathrm{KBr}(300 \mathrm{mg})$ and compressed to thin pellets by hydraulic pellet press. FTIR spectra were recorded in the range of $500-4000 \mathrm{~cm}^{-1}$ with a resolution of $4 \mathrm{~cm}^{-1}$ using an AVATAR 370 FTIR spectrometer (Thermo Nicolet, MA, USA).

The size and morphology of AgNPs were observed by scanning electron microscopy and transmission electron microscopy. One drop of the AgNP solution was applied onto a carbon-coated copper grid and dried under a lamp. AgNPs carried by the grid were observed with an SU8010 field emission scanning electron microscope (Hitachi, Tokyo, Japan) and a JEM-1230 transmission electron microscope (JEOL, Tokyo, Japan). The silver element of AgNPs was detected by an X-Max N energy dispersive spectrometer (Oxford Instruments, Oxford, UK) at $20 \mathrm{keV}$.

The crystalline nature of AgNPs was analyzed by X-ray diffraction spectroscopy. Freeze-dried AgNP powders were applied onto a coated film on a glass slide and analyzed using a D8 Advance Diffractometer (Bruker, Karlsruhe, Germany) in the $2 \theta$ range from $20^{\circ}$ to $80^{\circ}$ with $\mathrm{Cu}-\mathrm{K} \alpha$ radiation at $40 \mathrm{kV}$ and $40 \mathrm{~mA}$.

\subsection{Antibacterial Assays}

D. dadantii CZ1501 grown to midexponential phase was suspended with nutrient broth to about $5 \times 10^{8} \mathrm{CFU} \cdot \mathrm{mL}^{-1}$ before use.

Antibacterial activities against $D$. dadantii were first determined by the diffusion assay with agar plates. D. dadantii suspension was inoculated into the nutrient agar at about $45^{\circ} \mathrm{C}$ to $10^{7} \mathrm{cells} \cdot \mathrm{mL}^{-1}$; holes (7 $\mathrm{mm}$ in diameter) were made in the agar plates with sterilized steel punchers; CFCS (50\%) from cultures of the three plant growth-promoting strains, aqueous $\mathrm{AgNO}_{3}$ solution $\left(50 \mu \mathrm{g} \cdot \mathrm{mL}^{-1}\right)$, and aqueous AgNP solution $\left(50 \mu \mathrm{g} \cdot \mathrm{mL}^{-1}\right)$ were loaded into the holes and incubated for $24 \mathrm{~h}$ [47]. Antibacterial activities were evaluated by the diameters of the clearing zones formed around the holes. This experiment was done with three replications and repeated three times.

Antibacterial activities against $D$. dadantii growth in nutrient broth were further determined. $D$. dadantii suspension $(100 \mu \mathrm{L})$ was inoculated into nutrient broth $(5 \mathrm{~mL})$ and used as control. Equal volumes of CFCS of $P$. rhodesiae and nutrient broth were mixed; $D$. dadantii suspension $(100 \mu \mathrm{L})$ was added into the mixture $(5 \mathrm{~mL}) . \mathrm{AgNO}_{3}$ was added to nutrient broth to the final concentration of $50 \mu \mathrm{g} \cdot \mathrm{ml}^{-1}$. AgNPs synthesized with CFCS of P. rhodesiae were added into nutrient broth to final concentrations of 12,25 , and $50 \mu \mathrm{g} \cdot \mathrm{mL}^{-1}$. D. dadantii suspension $(100 \mu \mathrm{L})$ was inoculated into the nutrient broth $(5 \mathrm{~mL})$ containing $\mathrm{AgNO}_{3}$ or $\mathrm{AgNPs}$. The cultures were shaken at $200 \mathrm{rpm}$ and $30^{\circ} \mathrm{C}$ for $24 \mathrm{~h}$ and optical density at $600 \mathrm{~nm}\left(\mathrm{OD}_{600}\right)$ was measured using a SpectraMax spectrophotometer (Molecular Devices, Sunnyvale, CA, USA). This experiment was done with three replications and repeated three times. 
The swimming motility of $D$. dadantii was determined with semisolid nutrient agar $[0.3 \%(w / v)]$. Equal volumes of CFCS of $P$. rhodesiae and a semisolid nutrient agar $[0.6 \%(w / v)]$ were mixed at about $45{ }^{\circ} \mathrm{C} . \mathrm{AgNO}_{3}$ was added into a semisolid nutrient agar $[0.3 \%(w / v)]$ to the final concentration of $50 \mu \mathrm{g} \cdot \mathrm{mL}^{-1}$. AgNPs synthesized with CFCS of P. rhodesiae were added to final concentrations of 12, 25, and $50 \mu \mathrm{g} \cdot \mathrm{mL}^{-1}$. D. dadantii suspension $(5 \mu \mathrm{L})$ was spotted onto the center of the semisolid nutrient agar in Petri dishes and incubated at $30^{\circ} \mathrm{C}$ for $48 \mathrm{~h}$. The diameters of the colonies formed by $D$. dadantii were measured. This experiment was done with three replications and repeated three times.

Biofilm formed by $D$. dadantii was stained by crystal violet and quantified by absorbance at $590 \mathrm{~nm}$ $\left(\mathrm{OD}_{590}\right)$. D. dadantii suspension $(100 \mu \mathrm{L})$ was mixed with nutrient broth $(100 \mu \mathrm{L})$ and used as control. $\mathrm{AgNO}_{3}$ was added into nutrient broth to the concentration of $100 \mu \mathrm{g} \cdot \mathrm{mL}^{-1}$. AgNPs synthesized with CFCS of $P$. rhodesiae were added to concentrations of 24,50 , and $100 \mu \mathrm{g} \cdot \mathrm{mL}^{-1}$. D. dadantii suspension $(100 \mu \mathrm{L})$ was mixed with CFCS of $P$. rhodesiae $(100 \mu \mathrm{L})$ or the nutrient broth $(100 \mu \mathrm{L})$ containing $\mathrm{AgNO}_{3}$ $\left(100 \mu \mathrm{g} \cdot \mathrm{mL}^{-1}\right)$ or AgNPs $\left(24,50\right.$, or $\left.100 \mu \mathrm{g} \cdot \mathrm{mL}^{-1}\right)$. The mixtures were separately added into wells of a 96-well microplate while the nutrient broth was used as blank. After incubating at $30^{\circ} \mathrm{C}$ for $24 \mathrm{~h}$, the liquid in the wells was removed. The wells were washed three times with distilled water and then air-dried for $1 \mathrm{~h}$. The bacterial cells attached to the wells were stained with $1 \%(w / v)$ crystal violet $(200 \mu \mathrm{L})$ for $30 \mathrm{~min}$ at room temperature. The wells were then washed thoroughly with distilled water and air-dried for $1 \mathrm{~h}$. The crystal violet dye that stained the bacterial cells in the wells was dissolved with $33 \%(v / v)$ acetic acid $(200 \mu \mathrm{L})$ and $\mathrm{OD}_{590}$ was measured. This experiment was done with six replications and repeated three times.

In vivo antibacterial activity against $D$. dadantii was determined with sweet potato tuber slices. Sweet potato tubers were surface-sterilized with $70 \%(v / v)$ ethanol, washed with sterile distilled water, and cut into slices (10 $\mathrm{mm}$ in thickness). The tuber slices were immersed in distilled water (control), $50 \%(v / v)$ CFCS, $\mathrm{AgNO}_{3}$ solution $\left(50 \mu \mathrm{g} \cdot \mathrm{ml}^{-1}\right)$, or AgNP solutions $\left(12,25\right.$, or $\left.50 \mu \mathrm{g} \cdot \mathrm{mL}^{-1}\right)$ for $1 \mathrm{~h}$, and then put into Petri dishes and air-dried for $1 \mathrm{~h}$. Afterwards, D. dadantii suspension $(5 \mu \mathrm{L})$ was spotted in a puncture at the center of the tuber slice and incubated at $30{ }^{\circ} \mathrm{C}$ for $24 \mathrm{~h}$. Diameters of the maceration zones around the punctures were measured. This experiment was done with six replications and repeated three times.

\subsection{Transmission Electron Microscopy}

The effect of AgNPs on $D$. dadantii cell structure was determined by transmission electron microscopy. D. dadantii suspension and D. dadantii suspension containing AgNPs $\left(50 \mu \mathrm{g} \cdot \mathrm{mL}^{-1}\right)$ synthesized with CFCS of $P$. rhodesiae were incubated at $30^{\circ} \mathrm{C}$ with shaking at $200 \mathrm{rpm}$ for $2 \mathrm{~h}$ and $6 \mathrm{~h}$. D. dadantii cells were harvested by centrifugation and washed twice with $0.1 \mathrm{M}$ phosphate buffer ( $\mathrm{pH} 7$ ) and then fixed in $2.5 \%(v / v)$ glutaraldehyde in the phosphate buffer at $4{ }^{\circ} \mathrm{C}$ overnight. After washing with the phosphate buffer, $D$. dadantii cells were fixed in $1 \%(w / v) \mathrm{OsO}_{4}$ dissolved in the phosphate buffer for $1 \mathrm{~h}$ at room temperature. D. dadantii cells were then washed with distilled water and dehydrated by a graded series $(50 \%, 70 \%, 80 \%, 90 \%, 95 \%$, and $100 \%)$ of ethanol. Dehydrated $D$. dadantii cells were infiltrated by Spurr's resin at room temperature and embedded in Spurr's resin at 70 ${ }^{\circ} \mathrm{C}$ for $9 \mathrm{~h}$. Ultrathin sections were cut with glass knives on an ultramicrotome (Reichert-Jung, Vienna, Austria), collected with copper grids, stained with uranyl acetate and lead citrate, and observed with the JEM-1230 transmission electron microscope.

\subsection{Statistical Analysis}

Statistical analyses were done using the SPSS software version 16 (SPSS, Chicago, IL, USA) and the significance was set at $P<0.05$.

Author Contributions: Conceptualization, A.H. and B.L.; methodology, A.H., X.H., and E.I.; validation, B.L. and Q.A.; formal analysis, A.H. and X.H.; investigation, A.H., X.H., and E.I.; resources, E.I. and Y.M.; data curation, A.H. and X.H.; writing—original draft preparation, A.H. and X.H.; writing-review and editing, B.L., G.S., Y.M., 
Y.W., and Q.A.; visualization, A.H., X.H., and Q.A.; supervision, B.L. and Q.A.; project administration, Y.M. and Y.W.; funding acquisition, B.L., G.S., and Y.W.

Funding: This research was funded by Zhejiang Provincial Key Research and Development Program of China, grant number 2017C02002, Shanghai Agricultural Basic Research Project grant number 2014:7-3-1 and 2019-02-08-00-08-F01150, Zhejiang Provincial Natural Science Foundation of China, grant number LZ19C140002, National Key Research and Development Program of China, grant number 2017YFD0201104, Key Science and Technology Project of Ningbo, grant number 2016C11017, Fundamental Research Funds for the Central Universities, Dabeinong Funds for Discipline Development and Talent Training in Zhejiang University, and Key Subject Construction Program of Zhejiang for Modern Agricultural Biotechnology and Crop Disease Control.

Conflicts of Interest: The authors declare no conflict of interest. The funders had no role in the design of the study; in the collection, analyses, or interpretation of data; in the writing of the manuscript, or in the decision to publish the results.

\section{References}

1. Ma, B.; Hibbing, M.E.; Kim, H.-S.; Reedy, R.M.; Yedidia, I.; Breuer, J.; Breuer, J.; Glasner, J.D.; Perna, N.T.; Kelman, A.; et al. Host range and molecular phylogenies of the soft rot enterobacterial genera Pectobacterium and Dickeya. Phytopathology 2007, 97, 1150-1163. [CrossRef] [PubMed]

2. Charkowski, A.O. The changing face of bacterial soft-rot diseases. Annu. Rev. Phytopathol. 2018, 56, $269-288$. [CrossRef] [PubMed]

3. Liu, Q. Pathogen identification of a new bacterial rice foot rot disease in Guangdong province. J. South China Agric. Univ. 1997, 18, 128-129.

4. Pu, X.; Zhou, J.; Lin, B.; Shen, H. First report of bacterial foot rot of rice caused by a Dickeya zeae in China. Plant Dis. 2012, 96, 1818. [CrossRef] [PubMed]

5. Kumar, A.; Hunjan, M.S.; Kaur, H.; Rawal, R.; Kumar, A.; Singh, P. A review on bacterial stalk rot disease of maize caused by Dickeya zeae. J. Appl. Nat. Sci. 2017, 9, 1214-1225. [CrossRef]

6. Toth, I.; Van Der Wolf, J.; Saddler, G.; Lojkowska, E.; Hélias, V.; Pirhonen, M.; Tsror, L.; Elphinstone, J. Dickeya species: An emerging problem for potato production in Europe. Plant Pathol. 2011, 60, 385-399. [CrossRef]

7. McNally, R.; Curland, R.; Webster, B.; Robinson, A.; Ishimaru, C. First report of stem rot on potato caused by Dickeya chrysanthemi in Minnesota. Plant Dis. 2018, 102, 238. [CrossRef]

8. Jiang, H.H.; Hao, J.J.; Johnson, S.B.; Brueggeman, R.S.; Secor, G. First report of Dickeya dianthicola causing blackleg and bacterial soft rot on potato in Maine. Plant Dis. 2016, 100, 2320. [CrossRef]

9. Huang, L.; Fang, B.; Luo, Z.; Chen, J.; Zhang, X.; Wang, Z. First report of bacterial stem and root rot of sweetpotato caused by a Dickeya sp.(Erwinia chrysanthemi) in China. Plant Dis. 2010, 94, 1503. [CrossRef]

10. Shen, X.; Lin, C.; Qian, J.; Qiu, Z.; Chen, J.; Sun, C.; Yi, J.; Lou, B. Characterization of stem and root rot symptoms of sweet potato and the causal pathogen of the disease. Acta Phytopathol. Sin. 2018, 48, $25-34$.

11. Chaudhry, N.; Dwivedi, S.; Chaudhry, V.; Singh, A.; Saquib, Q.; Azam, A.; Musarrat, J. Bio-inspired nanomaterials in agriculture and food: Current status, foreseen applications and challenges. Microb. Pathog. 2018, 123, 196-200. [CrossRef] [PubMed]

12. Saratale, R.G.; Karuppusamy, I.; Saratale, G.D.; Pugazhendhi, A.; Kumar, G.; Park, Y.; Ghodake, G.S.; Bhargava, R.N.; Banu, J.R.; Shin, H.S. A comprehensive review on green nanomaterials using biological systems: Recent perception and their future applications. Colloids Surf. B Biointerfaces 2018, 170, $20-35$. [CrossRef] [PubMed]

13. Soni, M.; Mehta, P.; Soni, A.; Goswami, G.K. Green nanoparticles: Synthesis and applications. IOSR J. Biotechnol. Biochem. 2018, 4, 78-83.

14. Banasiuk, R.; Krychowiak, M.; Swigon, D.; Tomaszewicz, W.; Michalak, A.; Chylewska, A.; Ziabka, M.; Lapinski, M.; Koscielska, B.; Narajczyk, M. Carnivorous plants used for green synthesis of silver nanoparticles with broad-spectrum antimicrobial activity. Arab. J. Chem. 2017. [CrossRef]

15. Dzimitrowicz, A.; Motyka, A.; Jamroz, P.; Lojkowska, E.; Babinska, W.; Terefinko, D.; Pohl, P.; Sledz, W. Application of silver nanostructures synthesized by cold atmospheric pressure plasma for inactivation of bacterial phytopathogens from the genera Dickeya and Pectobacterium. Materials 2018, 11, 331. [CrossRef] [PubMed] 
16. Dzimitrowicz, A.; Motyka-Pomagruk, A.; Cyganowski, P.; Babinska, W.; Terefinko, D.; Jamroz, P.; Lojkowska, E.; Pohl, P.; Sledz, W. Antibacterial activity of fructose-stabilized silver nanoparticles produced by direct current atmospheric pressure glow discharge towards quarantine pests. Nanomaterials 2018, 8, 751. [CrossRef] [PubMed]

17. Mohammadi, A.; Hashemi, M.; Hosseini, S.M. Effect of chitosan molecular weight as micro and nanoparticles on antibacterial activity against some soft rot pathogenic bacteria. LWT-Food Sci. Technol. 2016, 71, 347-355. [CrossRef]

18. Sotelo-Boyas, M.E.; Valverde-Aguilar, G.; Plascencia-Jatomea, M.; Correa-Pacheco, Z.N.; Jimenez-Aparicio, A.; Solorza-Feria, J.; Barrera-Necha, L.; Bautista-Banos, S. Characterization of chitosan nanoparticles added with essential oils. In vitro effect on Pectobacterium carotovorum. Rev. Mex. Ing. Quim. 2015, 14, 589-599.

19. Velusamy, P.; Kumar, G.V.; Jeyanthi, V.; Das, J.; Pachaiappan, R. Bio-inspired green nanoparticles: Synthesis, mechanism, and antibacterial application. Toxicol. Res. 2016, 32, 95-102. [CrossRef]

20. Bhaskar, P.V.; Bhosle, N.B. Bacterial extracellular polymeric substance (EPS): A carrier of heavy metals in the marine food-chain. Environ. Int. 2006, 32, 191-198. [CrossRef]

21. Comte, S.; Guibaud, G.; Baudu, M. Biosorption properties of extracellular polymeric substances (EPS) towards Cd, $\mathrm{Cu}$ and $\mathrm{Pb}$ for different pH values. J. Hazard Mater. 2008, 151, 185-193. [CrossRef] [PubMed]

22. Anthony, K.J.P.; Murugan, M.; Gurunathan, S. Biosynthesis of silver nanoparticles from the culture supernatant of Bacillus marisflavi and their potential antibacterial activity. J. Ind. Eng. Chem. 2014, 20, 1505-1510. [CrossRef]

23. Elbeshehy, E.K.F.; Elazzazy, A.M.; Aggelis, G. Silver nanoparticles synthesis mediated by new isolates of Bacillus spp., nanoparticle characterization and their activity against bean yellow mosaic virus and human pathogens. Front. Microbiol. 2015, 6, 453. [CrossRef]

24. Padman, A.J.; Henderson, J.; Hodgson, S.; Rahman, P.K. Biomediated synthesis of silver nanoparticles using Exiguobacterium mexicanum. Biotechnol. Lett. 2014, 36, 2079-2084. [CrossRef] [PubMed]

25. Reddy, A.S.; Chen, C.Y.; Chen, C.C.; Jean, J.S.; Chen, H.R.; Tseng, M.J.; Fan, C.W.; Wang, J.C. Biological synthesis of gold and silver nanoparticles mediated by the bacteria Bacillus subtilis. J. Nanosci. Nanotech. 2010, 10, 6567-6574. [CrossRef]

26. Wei, X.T.; Luo, M.F.; Li, W.; Yang, L.R.; Liang, X.F.; Xu, L.; Kong, P.; Liu, H.Z. Synthesis of silver nanoparticles by solar irradiation of cell-free Bacillus amyloliquefaciens extracts and $\mathrm{AgNO}_{3}$. Bioresour. Technol. 2012, 103, 273-278. [CrossRef] [PubMed]

27. Schaad, N.W.; Brenner, D. Bacterial wilt and root-rot of sweet-potato caused by Erwinia chrysanthemi. Phytopathology 1977, 67, 302-308. [CrossRef]

28. Gao, B.; Wang, R.Y.; Chen, S.L.; Ma, J.; Li, X.H. First report of Pectobacterium carotovorum subsp carotovorum and P. carotovorum subsp odoriferum causing bacterial soft rot of sweet potato in China. Plant Dis. 2016, 100, 1776. [CrossRef]

29. Fouad, H.; Hongjie, L.; Yanmei, D.; Baoting, Y.; El-Shakh, A.; Abbas, G.; Jianchu, M. Synthesis and characterization of silver nanoparticles using Bacillus amyloliquefaciens and Bacillus subtilis to control filarial vector Culex pipiens pallens and its antimicrobial activity. Artif. Cells. Nanomed. B. 2017, 45, 1369-1378. [CrossRef]

30. Momin, B.; Rahman, S.; Jha, N.; Annapure, U.S. Valorization of mutant Bacillus licheniformis M09 supernatant for green synthesis of silver nanoparticles: Photocatalytic dye degradation, antibacterial activity, and cytotoxicity. Bioprocess Biosyst. Eng. 2019, 42, 541-553. [CrossRef]

31. Velmurugan, P.; Iydroose, M.; Mohideen, M.H.A.K.; Mohan, T.S.; Cho, M.; Oh, B.-T. Biosynthesis of silver nanoparticles using Bacillus subtilis EWP-46 cell-free extract and evaluation of its antibacterial activity. Bioprocess Biosyst. Eng. 2014, 37, 1527-1534. [CrossRef] [PubMed]

32. Mulvaney, P. Surface plasmon spectroscopy of nanosized metal particles. Langmuir 1996, 12, 788-800. [CrossRef]

33. Jyoti, K.; Baunthiyal, M.; Singh, A. Characterization of silver nanoparticles synthesized using Urtica dioica Linn. Leaves and their synergistic effects with antibiotics. J. Radiat. Res. Appl. Sci. 2016, 9, 217-227. [CrossRef]

34. Kumar, C.G.; Mamidyala, S.K. Extracellular synthesis of silver nanoparticles using culture supernatant of Pseudomonas aeruginosa. Colloids Surf. B Biointerfaces 2011, 84, 462-466. [CrossRef] [PubMed]

35. Singh, H.; Du, J.; Singh, P.; Yi, T.H. Extracellular synthesis of silver nanoparticles by Pseudomonas sp. THG-LS1.4 and their antimicrobial application. J. Pharm. Anal. 2018, 8, 258-264. [CrossRef] 
36. Kalimuthu, K.; Babu, R.S.; Venkataraman, D.; Bilal, M.; Gurunathan, S. Biosynthesis of silver nanocrystals by Bacillus licheniformis. Colloids Surf. B Biointerfaces 2008, 65, 150-153. [CrossRef]

37. Xiu, Z.-M.; Zhang, Q.-B.; Puppala, H.L.; Colvin, V.L.; Alvarez, P.J. Negligible particle-specific antibacterial activity of silver nanoparticles. Nano Lett. 2012, 12, 4271-4275. [CrossRef]

38. Ivask, A.; ElBadawy, A.; Kaweeteerawat, C.; Boren, D.; Fischer, H.; Ji, Z.; Chang, C.H.; Liu, R.; Tolaymat, T.; Telesca, D. Toxicity mechanisms in Escherichia coli vary for silver nanoparticles and differ from ionic silver. ACS Nano 2013, 8, 374-386. [CrossRef]

39. Ivask, A.; Kurvet, I.; Kasemets, K.; Blinova, I.; Aruoja, V.; Suppi, S.; Vija, H.; Käkinen, A.; Titma, T.; Heinlaan, M. Size-dependent toxicity of silver nanoparticles to bacteria, yeast, algae, crustaceans and mammalian cells in vitro. PloS ONE 2014, 9, e102108. [CrossRef]

40. Zawadzka, K.; Kądzioła, K.; Felczak, A.; Wrońska, N.; Piwoński, I.; Kisielewska, A.; Lisowska, K. Surface area or diameter-which factor really determines the antibacterial activity of silver nanoparticles grown onTiO ${ }_{2}$ coatings? New J. Chem. 2014, 38, 3275-3281. [CrossRef]

41. Duran, N.; Duran, M.; de Jesus, M.B.; Seabra, A.B.; Favaro, W.J.; Nakazato, G. Silver nanoparticles: A new view on mechanistic aspects on antimicrobial activity. Nanomed. NBM 2016, 12, 789-799. [CrossRef]

42. Reidy, B.; Haase, A.; Luch, A.; Dawson, K.; Lynch, I. Mechanisms of silver nanoparticle release, transformation and toxicity: A critical review of current knowledge and recommendations for future studies and applications. Materials 2013, 6, 2295-2350. [CrossRef] [PubMed]

43. Jahn, C.E.; Selimi, D.A.; Barak, J.D.; Charkowski, A.O. The Dickeya dadantii biofilm matrix consists of cellulose nanofibres, and is an emergent property dependent upon the Type III secretion system and the cellulose synthesis operon. Microbiology-SGM 2011, 157, 2733-2744. [CrossRef] [PubMed]

44. Prigent-Combaret, C.; Zghidi-Abouzid, O.; Effantin, G.; Lejeune, P.; Reverchon, S.; Nasser, W. The nucleoid-associated protein Fis directly modulates the synthesis of cellulose, an essential component of pellicle-biofilms in the phytopathogenic bacterium Dickeya dadantii. Mol. Microbiol. 2012, 86, 172-186. [CrossRef] [PubMed]

45. El-shakh, A.S.; Kakar, K.U.; Wang, X.; Almoneafy, A.A.; Ojaghian, M.R.; Li, B.; Anjum, S.I.; Xie, G.-L. Controlling bacterial leaf blight of rice and enhancing the plant growth with endophytic and rhizobacterial Bacillus strains. Toxicol. Environ. Chem. 2015, 97, 766-785. [CrossRef]

46. Zhang, F.; Li, X.-L.; Zhu, S.-J.; Ojaghian, M.R.; Zhang, J.-Z. Biocontrol potential of Paenibacillus polymyxa against Verticillium dahliae infecting cotton plants. Biol. Control 2018, 127, 70-77. [CrossRef]

47. Li, B.; Shan, C.-L.; Zhou, Q.; Fang, Y.; Wang, Y.-L.; Xu, F.; Han, L.-R.; Ibrahim, M.; Guo, L.-B.; Xie, G.-L. Synthesis, characterization, and antibacterial activity of cross-linked chitosan-glutaraldehyde. Mar. Drugs 2013, 11, 1534-1552. [CrossRef] [PubMed]

Sample Availability: Samples of the compounds are available from the authors.

(C) 2019 by the authors. Licensee MDPI, Basel, Switzerland. This article is an open access article distributed under the terms and conditions of the Creative Commons Attribution (CC BY) license (http://creativecommons.org/licenses/by/4.0/). 